\title{
Att värna om en minoritet inom en minoritet
}

\author{
Finlandssvenska dövas gränsposition och arbete för rättigheter $i$ \\ 1980-talets Finland
}

ÅreT 20I5 VAR EN MILSTOLPE i dövas historia i Finland, då teckenspråkslagen godkändes i riksdagen. Lagen innebär att teckenspråken i Finland ska främjas, och att personer vars modersmål är teckenspråk ska kunna använda det i kontakt med domstolar samt statliga och kommunala myndigheter. ${ }^{1}$ Den nya lagen är banbrytande på flera olika sätt; för första gången i Finlands historia är teckenspråkigas rättigheter till sitt modersmål tryggade i en särskild lag, och dessutom är den ett offentligt erkännande av Finlands båda teckenspråk. ${ }^{2}$ Vid sidan av det finska finns nämligen även ett finlandssvenskt teckenspråk som sedan sekelskiftet 1900 utvecklats inom det finlandssvenska dövsamfundet ${ }^{3}$ i Finland. Teckenspråkslagen är ett erkännande av detta dövsamfunds existens och en garanti för att medlemmarnas språkliga rättigheter

I. Teckenspråkslag (359/2015), Finlex, https://www.finlex.fi/sv/laki/alkup/2015/20150359 (hämtad 28/ro 20I9).

2. För teckenspråkets juridiska ställning före teckenspråkslagen se Markku Suksi, "Reglering av teckenspråkigas språkliga rättigheter", Tidskrift utgiven av Juridiska föreningen i Finland: JFT 2006:I, s. 153-I86.

3. I artikeln använder jag begreppen döva och dövsamfund för att beskriva den grupp som i första hand kommunicerar på teckenspråk, eftersom jag ser att dessa bäst motsvarar den historiska period jag studerar i artikeln. Begreppet hörselskadad, som vid tiden användes i officiella sammanhang och i tidningspressen, var inte ett accepterat begrepp inom dövsamfundet, medan begreppen teckenspråkig och teckenspråksgemenskap började användas allmänt först på r99o-talet. Såväl dövsamfund som teckenspråksgemenskap inkluderar personer som inte själva är döva, men som lever i nära anslutning till döva, såsom dövas hörande barn eller föräldrar. För diskussion om begrepp se Anja Malm \& Jan-Ola Östman, ”Viittomakieliset ja heidän kielensä", Anja Malm (toim.), Viittomakieliset Suomessa, Helsinki: Finn Lectura 2000, s. IO-I5. 
även i framtiden ska tryggas. Genom teckenspråkslagen blev de finlandssvenska döva en av de numerärt minsta minoriteter vars språkliga rättigheter tryggas i finsk lag, eftersom det i dag uppskattningsvis endast finns cirka 90 döva teckenspråksanvändare i Finland. ${ }^{4}$ Under slutet av I900-talet hade nämligen de finlandssvenska dövas möjligheter att leva och verka i Finland kringskurits och de flesta unga valde att bosätta sig permanent i Sverige.

Utvecklingen väcker frågan: hur kommer det sig att finlandssvenska döva trots det har nått en position där just deras språkliga rättigheter tryggas i lag? Och i förlängningen: vilka möjligheter har det funnits för en så liten minoritet att arbeta för sina rättigheter och på vilka sätt har kraven blivit emottagna? I den här artikeln visar jag att teckenspråkslagen var ett resultat av flera decenniers arbete för dövas rättigheter och jag fokuserar på utvecklingen bland de finlandssvenska döva, vars villkor och rättigheter har påverkats av flera minoritetspositioner. För att hitta svar på frågorna kommer jag att rikta blicken mot det sena I90o-talet och framför allt I980-talet, då minoritetsrättigheter kom upp på den politiska dagordningen och de finlandssvenska döva aktivt började arbeta för sina språkliga, utbildningsmässiga och sociala rättigheter. I artikeln fokuserar jag speciellt på hur rätten till teckenspråk i kombination med rätten till en god utbildning lyftes fram som den enskilt viktigaste frågan. Dessutom analyserar jag hur arbetet igångsattes, vilka som var de drivande aktörerna och vilka frågor de arbetade för. Jag ämnar även se på växelverkan mellan det finlandssvenska dövsamfundet och de institutioner som bevakade dövas och svenskspråkigas rättigheter, såsom Finlands Dövas Förbund (härefter endast Dövas Förbund) och Svenska folkpartiet (SFP). Ämnet studeras genom ett brett källmaterial, innefattande arkivmaterial från Dövas Förbunds svenskspråkiga arbetsgrupp och dövskolan i Borgå, finlandssvenska dagstidningar och tidskrifter för döva eller specialiserade på frågor rörande döva, samt intervjuer med några av de ledande aktörerna inom det finlandssvenska dövarbetet på ig8o-talet.

4. Maria Andersson-Koski, Mitt eget språk-vårkultur. En kartläggning av situationen for det finlandssvenska teckenspråket och döva finlandssvenska teckenspråkiga i Finland 20I4-20I5, Helsingfors: Finlandssvenska teckenspråkiga r.f. 20I5, s. 35, http:// www.dova.fi/wp-content/uploads/2015/o7/PDF_Mitt_eget_sprak_var_kultur.pdf (hämtad 20/9 20I9). 
Forskningen om finlandssvenska döva kan med fog sägas vara bristfällig. Det föreligger endast två mera djupgående studier: Monica Londens doktorsavhandling om finlandssvenska dövas utbildningsmöjligheter i slutet av I990-talet och början av 2000-talet, samt Karin Hoyers doktorsavhandling om språkplanering och ordboksarbete inom tecknade minoritetsspråk. ${ }^{5}$ I båda dessa beaktas även språkgruppens historiska och kulturella dimensioner. Den historiska forskningen är begränsad till dövföreningarnas egna historiker och utgivning. Birgitta Wallvik har författat två verk som behandlar finlandssvenska dövas historia, men då i huvudsak med fokus på det tidiga I9oo-talet. ${ }^{6}$ I Eeva Salmis och Mikko Laaksos digra Ioo-årshistorik över Dövas Förbund, Maahan lämpimään. Suomen viittomakielisten historia (2005), behandlas de finlandssvenska döva ytterst knapphändigt. Den befintliga litteraturen visar dock att finlandssvenska döva utgör en social gemenskap. Då man talar om finlandssvenska döva är det alltså inte fråga om enskilda individer som skulle vara spridda runt Svenskfinland utan närmare kontakt med varandra, utan ett dövsamfund med en gemensam kultur och historia samt ett gemensamt språk. Detta faktum har starkt bidragit till synen på finlandssvenska dövas rättigheter och arbetet för dem.

Syftet med den här artikeln är att synliggöra en liten grupps minoritetskonstituering och arbete för rättigheter, men detta görs inte endast för att gruppen och dess historia är understuderade. Genom att placera finlandssvenska döva i centrum och analysera deras arbete för språkliga, utbildningsmässiga och sociala rättigheter, kan man studera gränser för och möjligheter till medborgarskap och tillhörighet för en minoritet inom en minoritet, samt vilka frågor som uppmärksammades

5. Monica Londen, Communicational and Educational Choices for Minorities within Minorities. The Case of the Finland-Swedish Deaf, Helsinki: Helsinki University Press 2004; Karin Hoyer, Dokumentation och beskrioning som språkplanering - perspektiv från arbete med tre tecknade minoritetsspråk, Nordica Helsingiensia 29, Helsingfors: Nordica 20I2. Det finns även en publicerad avhandling pro gradu i specialpedagogik om Borgå dövskola. Anna-Lena Eriksson, Anna-Lena West \& Britta Hannus-Gullmets, Dörskolan i Borgå 1946-1993, Vasa: Institutionen för specialpedagogik 1995 .

6. Birgitta Wallvik, Du måste vara döv för att förstå. Finlandssvenska dövas fotspår $i$ bistorien, Helsingfors: Finlandssvenska teckenspråkiga r.f. 2005; Birgitta Wallvik, Från Dövstumsbacken till Solsand - Teckenspråkig kultur i Jakobstadsnejden, Jakobstad: Jakobstads Nejdens döva 2016. 
och metoder som användes när de finlandssvenska döva arbetade för sin sak i I98o-talets Finland. Då vi talar om rättigheter och medborgarskap har döva personers villkor överlag, och finlandssvenska dövas i synnerhet, varit påverkade av flera rättighetsfält. För att illustrera situationen för döva i EU:s medlemsstater har Mark Wheatley och Annika Pabsch utvecklat följande figur:

\section{Teckenspråksrättigheter $=$ Mänskliga rättigheter}

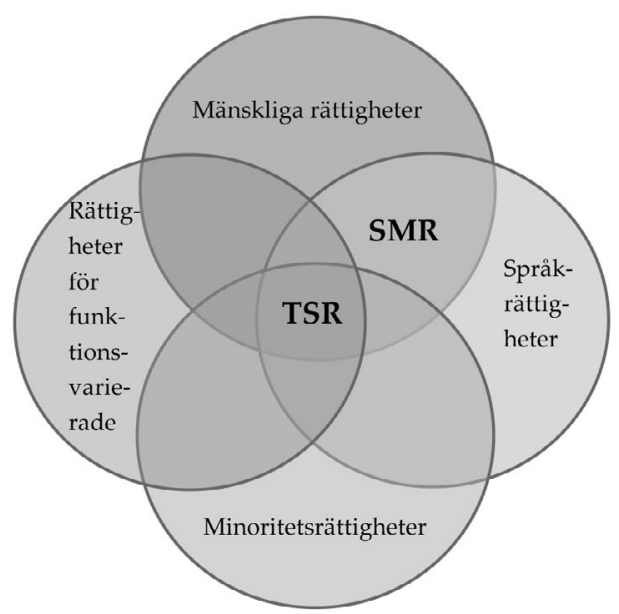

SMR: Språkliga mänskliga rättigheter

TSR: Teckenspråksrättigheter

Döva har påverkats av föreställningar om minoritetsrättigheter, språkliga rättigheter, rättigheter för funktionsvarierade och mänskliga rättigheter, och i skärningspunkten mellan alla dessa ligger teckenspråksrättigheter, som dövsamfunden i Europa under 2000-talet har koncentrerat sig på. ${ }^{7}$ Då man studerar dövas situation och arbetet för dövas rättigheter längre tillbaka i tiden, eller inom specifika döv-

7. Mark Wheatley \& Annika Pabsch, Sign Language Legislation in the European Union, 2nd edition, Brussels: EUD 2012, s. 28. 
samfund, är dock inte alla fält nödvändigtvis lika viktiga eller ens relevanta. I vilken mån baserade sig arbetet för finlandssvenska dövas rättigheter på argument om språk, minoritetskap, funktionsvariation eller mänskliga rättigheter?

I sin genomgång av teckenspråket i finländsk lagstiftning konstaterar Markku Suksi att rättigheter aldrig är självklara, utan situationsbundna och alltid tolkningsbara. På samma sätt handlar medborgarskap inte endast om formella rättigheter, utan även om känslan av delaktighet och praktiska möjligheter att delta i samhället. ${ }^{8}$ Finlandssvenska dövas situation har på flera sätt varit paradoxal. Genom sin delaktighet i den finlandssvenska språkgruppen har formella rättigheter till framför allt utbildning på svenska varit garanterade, och även annan service för döva ska i teorin även erbjudas på svenska. För denna minoritet inom den svenska språkgruppen har den faktiska tillgången till dessa rättigheter dock varit begränsad. Vilka implikationer detta har fătt för de finlandssvenska döva kommer jag att analysera närmare $\mathrm{i}$ artikeln.

\section{AtT SKAPA OCH MEDVETANDEgÖRA EN MinoriteT}

Som jag nämnde ovan studerar jag i den här artikeln I980-talet, eftersom det var då som ett aktivt och organiserat arbete för finlandssvenska dövas rättigheter initierades. Att det var just I980-talet är ingen slump; det var en följd av det tidigare årtiondets minoritets- och medborgaraktivism, som inte endast innefattade etniska minoriteter utan även personer med funktionsvariationer. Till skillnad från de flesta andra minoriteter som vid den här tiden kämpade för ett erkännande av sina språkliga och kulturella rättigheter, kan man för dövas del ange ett årtal för när gruppen "föddes", nämligen år I846 då den första dövskolan i Finland grundades i Borgå av Carl Oscar Malm. Trots att döva personer alltid hade funnits och att någon form av teckenspråk troligtvis har använts i samhällen med flera döva, innebar koncentrationen av döva till dövskolorna med tillhörande elevhem att nationella tecken-

8. Suksi, "Reglering av teckenspråkigas språkliga rättigheter", s. I54; Bryan S. Turner, "Contemporary problems in the theory of citizenship", Bryan S. Turner (ed.), Citizenship and Social Theory, London: Sage 1993, s. 2. 
språk utvecklades samt att dövas politiska formering senare kunde ta vid. Runt skolorna uppkom dövsamhällen, och dövundervisningens utformning samt skolornas verksamhetssätt skapade villkoren för döva personers liv. Det har inneburit att dövas historia alltid på ett eller annat sätt är knuten till skolorna och dövundervisningen. ${ }^{9}$

Därför är även finlandssvenska dövas historia knuten till de svenska dövskolorna i Finland, och framför allt Borgå dövskola, som mellan I932 och I993 var den enda dövskolan på svenska i Finland. Ursprungligen hade dövskolorna varit gemensamma för elever från finsk- och svenskspråkiga hem, men skolorna delades på språklig grund I892. Skolorna i Borgå och Jakobstad (I863-I932) reserverades för de svenska eleverna och runt dem utvecklades kulturer och varieteter av teckenspråket som med tiden skulle komma att karakterisera den finlandssvenska dövgemenskapen. Trots att skolorna var delade på språklig grund var finska och finlandssvenska döva del av ett gemensamt nationellt dövsamfund. Medan exempelvis Belgien såg en allt starkare antagonism under loppet av i9oo-talet mellan den vallonska och den flamländska dövgruppen med separata dövföreningar, gick de finska och finlandssvenska ihop och verkade gemensamt inom Dövas Förbund och de lokala dövföreningarna. ${ }^{10}$ Många av det sena I8oo-talets och det tidiga r9oo-talets ledande gestalter inom den finländska dövvärlden var dessutom från svenskspråkiga familjer, och därför hade även de svenska döva en framträdande position under perioden.

9. Se t.ex. Joseph J. Murray, "Transnational interconnections in nineteenth-century Western deaf communities", Michael Rembis, Catherine Kudlick \& Kim E. Nielsen (eds.), The Oxford Handbook of Disability History, Oxford: Oxford University Press 2018, s. 428, https://doi.org/ro.Io93/oxfordhb/9780190234959.013.25; Eeva Salmi, "Kielelliset käänteet kuurojen opetuksessa", Joel Kivirauma (toim.), Muuttuvat marginaalit: näkökulmia vammaistutkimukseen, Helsinki: Kehitysvammaliitto ry. 2008, s. Io-4I; Bencie Woll, Rachel Sutton-Spence \& Frances Elton,"Multilingualism. The global approach to sign languages", Ceil Lucas (ed.), The Sociolinguistics of Sign Languages, Cambridge: Cambridge University Press 200I, s. I2, https://doi. org/Io.Ior7/CBO97805116I2824.004.

Io. Om de belgiska dövsamfunden se t.ex. Mieke Van Herreweghe, Maartje De Meulder \& Myriam Vermeerbergen, "From erasure to recognition (and back again?): The case of Flemish sign language", Marc Marschark \& Patricia Elizabeth Spencer (eds.), The Oxford Handbook of Deaf Studies in Language, Oxford: Oxford University Press 20I6, s. 46, https://doi.org/Io.Io93/oxfordhb/978019024I4I4.or3.4. 
I90o-talets första hälft karaktäriserades av en tid av förtryck och kringskurna rättigheter, som tog sig uttryck dels i förbudet mot teckenspråk i dövundervisningen, dels i äktenskapsförbud. Mellan I892 och I957 var den så kallade oralismen förhärskande i dövskolorna, enligt vilken teckenspråket inte skulle användas. Döva skulle i stället kommunicera genom tal och läppavläsning i syfte att bli så delaktiga i det hörande samhället som möjligt. ${ }^{11}$ Samma utveckling skedde också globalt och oralismen infördes i de flesta länder i och med den resolution mot teckenspråket som Milanokongressen i dövundervisning antog 1880. Döva var även i många länder utsatta för sterilisering och andra eugeniska åtgärder för att hindra ärftlig dövhet, och Finland var ett av få länder med äktenskapsförbud för två döva med medfödd eller ärftlig dövhet (I929 till I969). ${ }^{12}$

Det fanns dock redan tidigt ett engagerat motstånd mot äktenskapsförbudet och ett aktivt engagemang inom Dövas Förbund för att öka teckenspråkets status. Från i950-talet framåt rapporterade Dövas Förbunds språkrör Tidskrift för Döva kontinuerligt om teckenspråkets förtjänster och om dövas rätt till sitt språk. Även arbetet för finlandssvenska dövas möjligheter och rättigheter hade påbörjats redan före I980-talet. Då planerna för yrkesutbildning för döva pågick under I930- och I940-talen, framstod de svenskspråkiga dövas behov av utbildning som synnerligen problematiska att tillgodose. Trots att invalidvårdslagen stipulerade att funktionsnedsatta hade rätt till avgiftsfri yrkesutbildning, var de finlandssvenska döva för få till antalet för att det skulle vara möjligt att grunda en egen yrkesskola med olika utbildningslinjer. ${ }^{13}$ På grund av avsaknaden av yrkesutbildning på svenska började en utbildningsemigration till Sverige och detta hade staten och dövlärarna som ambition att stävja. ${ }^{14}$ Här

II. För en utförlig redogörelse för både oralismen och rashygieniska initiativ mot döva personer i Finland se Eeva Salmi \& Mikko Laakso, Maahan lämpimään. Suomen viittomakielisten historia, Helsinki: Kuurojen liitto ry. 2005.

I2. Salmi \& Laakso, Maahan lämpimään, s. 204; Eeva Salmi, Linguistic Turns in Teaching of the Deaf in Finland, Helsinki: Humanistinen ammattikorkeakoulu 2oro, s. 32.

I3. Heikki Waris, Suomalaisen ybteiskunnan sosiaalipolitiikka, Porvoo \& Helsinki: WSOY 1961, s. 257; Kuuromykkäin ammattiopetuskomitean mietintö, komiteamietintö n:o 7 I939, Helsinki I939.

I4. Terminens inlednings- och avslutningstal [I945-I964], Dövskolans i Borgå arkiv, Riksarkivet, Tavastehus. 
fördes diskussionen dock inte i huvudsak av döva själva utan inom de institutioner som arbetade med döva. Det samma kan sägas om diskussionen kring sammanslagningen av tidskrifterna Kuurojen Lehti och Tidskrift forr Döva som skedde I95I och som väckte känslor både på svenskt och finskt håll. ${ }^{15}$

1970- och 1980-talen var centrala årtionden, eftersom det var då som pendeln svängde och de berörda grupperna själva förde fram krav och önskemål. I USA började döva som var verksamma vid Gallaudet College i Washington D.C. i början av 1970-talet använda begreppet deaf awareness, dövmedvetenhet, med syftet att öka kunskapen om dövas liv och villkor. I första hand var det de döva själva som skulle medvetandegöras om att teckenspråket var ett fullvärdigt språk och att de hade rätt till sitt modersmål. All form av integrering på de hörandes villkor, och framför allt oralismen, var en grov kränkning av dövas rättigheter. Det som kom att kallas dövmedvetenhetsrörelsen framförde att dövhet i sig inte var ett handikapp, utan att en funktionsnedsättning alltid var kontextbunden; en döv var fullt funktionell i sällskap av andra döva, där det i stället var de hörande som var funktionsnedsatta. ${ }^{16}$

Diskussionen om dövmedvetenhet fokuserade alltså på teckenspråket, och dövas rätt till språket i olika situationer. Det bör påpekas att det i diskussionen inte ingick krav på medicinsk intervention mot dövhet eller tekniska hjälpmedel för att möjliggöra hörsel. Exempelvis hörapparaten uppfattades i stället som ett onödigt och stigmatiserande föremål som markerade döva som annorlunda. ${ }^{17}$ Döva skulle i första hand uppfattas som en språklig och kulturell minoritet, i Norden jämförbar med till exempel samer eller romer. ${ }^{18}$ På det här sättet uppstod ett ambivalent förhållande till begreppet handikapp; å ena

15. En upprörd läsare skrev 1957 i Hufvudstadsbladet att de finlandssvenska döva hade lurats att gå med på sammanslagningen. Den upprörda läsaren var troligtvis någon i Borgå dövskolas lärarkår, som vid tiden för sammanslagningen skötte om utgivningen av den svenska tidskriften. Signaturen Borgåbo,"Döv(stum) finskhetsiver?", Hufvudstadsbladet 6/5 I957.

16. Salmi \& Laakso, Maahan lämpimään, s. 303.

17. Se t.ex. Karin Saarikoski, "Dövmedvetenhet - vad är det?", Nappi 1982:5-6, s. I5.

I8. Se t.ex. Liisa Kauppinen \& Raija Nieminen, "Döva en språklig minoritet", Tidskrift för Döva 1983:20, s. I3. 
sidan tryggades rättigheter genom handikapplagar, å andra sidan skulle inte begreppet handikapp användas för att beskriva döva som grupp. ${ }^{19}$

Dövmedvetenhetsrörelsen var ett led i den omfattande medborgaraktivismen bland diskriminerade grupper och arbetet för minoriteters rättigheter och självbestämmanderätt under i96o-talets slut och på I970-talet. Idén om dövmedvetenhet nådde de nordiska länderna i slutet av I970-talet, men såsom Salmi och Laakso påpekar cirkulerade liknande diskussioner i Finland redan tidigare. Begreppet dövmedvetenhet gav dock diskussionen stadga och visade att kampen för teckenspråk och dövas rättigheter var ett globalt fenomen. I de nordiska länderna fick dövmedvetenhetsrörelsen speciellt stort genomslag i Sverige och Danmark, och i förlängningen även i Finland. Det första dövmedvetenhetsseminariet ordnades år 1980 och dövmedvetenhet diskuterades aktivt på Tidskrift för Dövas sidor. Samtidigt började ett allt intensivare arbete för teckenspråket och framför allt för teckenspråkig undervisning. ${ }^{20}$

\section{RÄTT TILL TECKENSPRÅKIG UNDERVISNING}

Även på finlandssvenskt håll följde man med det förändrade klimatet beträffande inställningen till teckenspråk och dövas rättigheter. Brita Edlund, som är mor till två döva söner och som hade en central position i arbetet för finlandssvenska döva under i980-talet, tog del av all den utveckling för dövas rättigheter och teckenspråkets ställning som skedde i Sverige. Där började man redan på 1970-talet forska i teckenspråk och föra en aktiv politik för att få det erkänt som dövas modersmål. ${ }^{21}$ Det konkreta arbetet för finlandssvenska dövas rättigheter kom dock igång för att svara på de reella hot och svårigheter som mötte en grupp som levde i skärningspunkten mellan etnicitet, funktionsvariation och språk. De följande avsnitten är indelade enligt de stora frågor som arbetet för finlandssvenska döva kretsade kring, nämligen teckenspråkig undervisning och svenskspråkig information.

I9. Joseph J. Murray, "Linguistic human rights discourse in deaf community activism", Sign Language Studies 15, 2015:4, s. 384, 396, https://doi.org/10.1353/sls.2015.0012.

20. Salmi \& Laakso, Maahan lämpimään, s. 302-306.

2I. Intervju med Brita Edlund 23/5 2019. Intervjuinspelning i författarens ägo. 
Som jag framförde i föregående avsnitt har undervisning varit den enskilt viktigaste frågan som berört döva. Döva var den första grupp som fick specialundervisning och de villkor som döva levt under har stått i relation till den rådande synen på hur döva ska undervisas. ${ }^{22}$ Därför har den klart största och viktigaste frågan även för finlandssvenska döva varit hur skolgång och utbildning ska garanteras och organiseras för döva barn i svenskspråkiga familjer. Det faktum att det över huvud taget finns ett finlandssvenskt dövsamfund hänger ihop med att man hade egna skolor för döva från svenskspråkiga familjer. Detta var i sin tur ett resultat av det sena I8oo-talets uppdelning av institutioner på språklig grund och svenskans status som officiellt språk i Finland i samband med självständigheten, varigenom svensk undervisning på ett eller annat sätt skulle tryggas för döva barn.

Även om de finlandssvenska dövas rättigheter och villkor diskuterats redan tidigare, var de som tidigare hade fört talan nästan uteslutande hörande experter eller lärarna vid Borgå dövskola. Från slutet av 1970-talet började medlemmarna i det finlandssvenska dövsamfundet, både de som själva var döva och de som hade döva barn eller föräldrar, själva föra ordet. Det som satte igång processen var hotet om att Borgå dövskola skulle stängas på grund av elevbrist. Under i960-talet och i början av 1970-talet vände trenden i dövundervisningen så att allt fler förespråkade så kallad "normalisering" där döva och hörselnedsatta barn skulle integreras med hörande elever i kommunala skolor. Grundskolereformens (I968) ideal om jämlikhet och demokrati i undervisningen skulle även omfatta barn i behov av specialundervisning, och därför sågs isoleringen av döva barn i särskilda dövskolor som skadlig för kontakten med hemmet och också för möjligheten att integreras i det omgärdande samhället. År 1972 blev det därför möjligt för kommunerna att bilda så kallade hörselklasser där barn med olika grader av hörselnedsättning undervisades tillsammans. ${ }^{23}$

För finlandssvenska döva barn var dock en kommunalisering av dövundervisningen inte möjlig, eftersom de döva och hörselnedsatta

22. Se t.ex. Tuula Vuolle,"Vammaisten koulukysymys Suomessa I8oo-luvun loppuun", Toivo Nygård \& Kari Tuunainen (toim.), Avun kohteesta itsensä auttajaksi. Katsaus Suomen vammaishistoriaan, Jyväskylä: Atena Kustannus Oy I996, s. 49-II2.

23. Salmi \& Laakso, Maahan lämpimään, s. 343-346. 
barnen var utspridda över många olika orter i Svenskfinland. Trots att det var praktiskt omöjligt att kommunalisera den svenskspråkiga dövundervisningen uppstod det kritik från föräldrahåll i tidningspressen mot Borgå dövskola, där skolans avlägsna plats i förhållande till stora delar av Svenskfinland samt skolbyggnadernas dåliga skick lyftes fram. Exempelvis Greta Ahlskog från Vasa kritiserade i flera artiklar dövskolan och hur dövundervisningen organiserades för finlandssvenska elever. ${ }^{24}$

Mot I970-talets slut började också elevantalet dala. Läsåret I977I978 hade skolan endast nio elever och därför drogs flera tjänster in, samtidigt som föreståndartjänsterna för skolan och elevhemmet sammanslogs. Enligt skolans föreståndare Greta Wisuri var beslutet dock förhastat, eftersom det rådde stor fluktuation från år till år i antalet döva barn som föddes i Svenskfinland, och prognoserna visade att elevantalet igen skulle stiga under de följande åren. ${ }^{25}$ Bland de föräldrar, såväl hörande som döva, som hade barn som antingen redan gick i skolan eller som strax skulle börja där uppkom stark oro för skolans och barnens framtid, som konstant upplevdes ligga i vågskålen. Enligt Brita Edlund fanns det även visst fog för kritiken. Skolbyggnaden var ytterst sliten, och det stod klart att omfattande resurser behövdes för att kunna garantera fortsatt dövundervisning på svenska i Finland. ${ }^{26}$

För att få de resurser man behövde och skapa kontinuitet gick föräldrarna samman och grundade Döva och hörselskadade barns stödförening r.f. (DHBS) 1979 med Edlund som första ordförande. Det fanns redan ett nationellt föräldraförbund, Hörselskadade barns föräldraförbund, som under ledning av Michael Tillander aktivt arbetade för döva barns utbildning och rätt till teckenspråk. Tillander var svenskspråkig och far till en döv dotter född i slutet av i96o-talet, men för dottern valdes finsk dövskola uttryckligen på grund av Borgåskolans osäkra ställning och den i övrigt dåliga servicen för svensk-

24. Gus Söderlund, "Hörselskadade barn - diskrimineras de?", Borgåbladet 30/4 I971; Britta Lindblom, "Dövskolan bäddar inte för liv i anstalt", Borgåbladet 30/12 I975.

25. Lena Selén,"Dövskolan inskränker nästa höst", Borgåbladet Io/5 1977; Signaturen Aje, "Landets äldsta skola fyller I30 år", Hufvudstadsbladet 30/9 1976.

26. Intervju med Brita Edlund 23/5 20I9; Jan-Erik Andelin, "'Allt tog slut med dövskolan", Borgåbladet 24/II 20I2, s. I2. 
språkiga döva. ${ }^{27}$ Tvåspråkiga familjers val av finsk skola för sina döva barn var en av de trender som DHBS försökte svänga.

Arbetet för förbättrade undervisningsvillkor för finlandssvenska döva omfattade en rad olika områden och frågor. Det mest akuta var att få till stånd en renovering av skolbyggnaden. För att säkra de medel som behövdes för en totalrenovering av skolan krävdes ett nära samarbete med Undervisningsministeriet. Bland medlemmarna i DHBS och den svenska arbetsgrupp som år 198I tillsattes vid Dövas Förbund fanns flera personer som hade nära kontakter till Svenska folkpartiet, och därför var dialogen med de ledande politikerna relativt smidig. ${ }^{28}$ Under 1970-talets slut och i början av r980-talet var bland andra Kristian Gestrin och Pär Stenbäck undervisningsministrar. Finansieringen för skolrenoveringen säkerställdes år I980, då 2,2 miljoner mark reserverades för ändamålet, och I 982 kom slutligen renoveringen i gång. Förutom att förbättra själva byggnaden installerade man även teknisk apparatur som behövdes dels för att förmedla ljudet till hörapparaterna bättre, dels för att stärka andra sinnen. Genom renoveringen som var färdig 1983 omvandlades skolan till en ytterst modern dövskola som fyllde de specialbehov undervisningen krävde. ${ }^{29}$

En annan pressande fråga handlade om ökad regional rättvisa. Som ovan nämndes blev kritiken mot elevhemsboendet, som för eleverna vid dövskolorna startade redan vid sex års ålder, allt starkare under I970-talet. Även om elevantalet inte räckte för egna klasser, ville föräldrarna i Österbotten ändå försäkra sig om en något senarelagd skolgång i Borgå. Därför framfördes idén om att döva barn skulle ha möjlighet att gå de två förskoleåren i Österbotten, och flytta till Borgå dövskola i 8-årsåldern. Kraven var i sig inte nya; mellan I863 och 1932 verkade en dövskola först i Pedersöre och sedan i Jakobstad och i samband med kommunaliseringen av dövundervisningen framfördes även tankar på ett eget skolcentrum för finlandssvenska elever

27. "Arbete och resor", Nappi i984:2, s. I4.

28. Intervju med Brita Edlund 23/5 2019; intervju med Håkan Westerholm 30/9 2019. Intervjuinspelning i författarens ägo.

29. Direktionens mötesprotokoll I982, I983, Dövskolans i Borgå arkiv, Riksarkivet, Tavastehus; "Dövskolan i Borgå fick i går 2,2 milj.", Borgåbladet I2/4 I980; "Skönt att beslutsfattarna anser att Dövskolan behövs", Borgåbladet 8/6 I983. 
i Vasa. ${ }^{30}$ Även i den här frågan var kontakten till ledande politiker av stor vikt, och SFP-politikern Ole Norrback var en av de drivande personerna. Också undervisningsminister Stenbäck tog ställning för de österbottniska kraven på förskoleundervisning i närområdet. Planerna skred raskt fram. En barnträdgårdslärare skickades till Borgå I98I för att förbereda arbetet med döva barn och år 1983 öppnade specialdaghemmet i Ytteresse sina dörrar. ${ }^{31}$ I Borgå väckte dock det österbottniska kravet oro för att daghemsverksamhet på sikt skulle leda till förnyade krav på en egen skola, vilket i sin tur kunde skada skolan i Borgå. ${ }^{32}$ Oron var kanske inte helt obefogad, eftersom de österbottniska eleverna mot slutet av i980-talet och i början av i99o-talet i allt mindre utsträckning valde Borgå som skolgångsort, vilket jag återkommer till senare.

Det var inte endast kvaliteten på själva skolhuset som skulle förbättras, utan även på den undervisning som skedde innanför skolans väggar. Förbudet mot att använda teckenspråk i dövundervisningen hade avlägsnats 1957, men det betydde inte en omedelbar övergång från oralismen till teckenspråket. På 1960- och 1970-talen övergick skolorna till den så kallade simultanmetoden, eller total kommunikation, som gick ut på att lärarna samtidigt använde tal och tecken. På det här sättet blev tecknen ett stöd för talet och följde talets ordföljd och grammatik, ett system som fick namnet tecknad svenska. Trots att simultanmetoden medförde en ökad acceptans för teckenspråket, var den problematisk. Teckenspråkens grammatik och logik är annorlunda än de talade språkens, och därför blev ett teckenspråk som följde talspråket konstgjort och svårt att förstå. I dövskolorna fanns det inte heller några entydiga krav på lärarnas kunskaper i teckenspråk. Dövas Förbund ordnade kurser, men lärarnas närvaro på kurserna varierade, och i stället lärde de sig teckna av sina elever. ${ }^{33}$

30. "Svenskt skolcentrum för döva till Vasa?”, Borgåbladet 4/2 I969; För information om dövskolan i Jakobstad se Wallvik, Från Dörstumsbacken till Solsand.

31. Signaturen Bredlund [Brita Edlund], "Smått och gott från DHSF",Nappi 1980:4; "De handikappade bör få bättre utbildning", Hufvudstadsbladet 6/4 I98I.

32. Direktionens mötesprotokoll ı980, Dövskolans i Borgå arkiv, Riksarkivet, Tavastehus.

33. Salmi, "Kielelliset käänteet kuurojen opetuksessa", s. 25-28. 
Teckenspråket var inte heller inskrivet i lagen om dövundervisning, vilket var en fråga som Dövas Förbund och Hörselskadade barns föräldraförbund starkt engagerade sig i vid slutet av I970-talet och i början av 1980-talet. Ett intensifierat arbete för teckenspråket tog vid från och med I980, då en omfattande demonstration för dövas rättigheter ordnades vid riksdagshuset i Helsingfors i samband med att Dövas Förbund fyllde 75 år. Förbundet ställde krav på att teckenspråket skulle erkännas som dövas modersmål, och att tolktjänsterna för döva, som året innan hade stadgats i lag, skulle förbättras. I demonstrationerna deltog förutom vuxna finlandssvenska döva även eleverna från Borgå dövskola för att skapa mera synlighet för gruppen. ${ }^{34}$ I samband med att grundskolelagen reformerades I983, såg de båda förbunden sin chans att garantera teckenspråkig undervisning för döva barn, men det enda som infogades i lagen var en skrivelse om att teckenspråk kunde användas som ett stöd i undervisningen. ${ }^{35}$

Trots att teckenspråket inte infördes som undervisningsspråk i grundskolelagen innebar teckenspråkets statushöjning en helt ny situation i dövskolorna. Medan det tidigare hade varit vanligt att döva barn kom till skolan utan något språk över huvud taget och utan ett gemensamt språk med sina hörande familjemedlemmar, hade både barnen och föräldrarna nu kunskap i teckenspråket från en tidig ålder. Från och med r970-talet började nämligen föräldrarna ta del av teckenspråkskurser ordnade av bland andra Dövas Förbund och DHBS, och därigenom kommunicera med sina döva barn på teckenspråk. Bland dessa barn och föräldrar fanns högre förväntningar på lärarnas teckenspråkskunskaper, och i förlängningen på den undervisning som lärarna kunde erbjuda på teckenspråket. Enligt Birgitta Wallvik, som var verksam i flera olika roller vid både Dövas Förbund och dövskolan i Borgå under I980-talet, uppstod problemen främst i de högre klasserna där lärarnas kommunikationsförmåga inte längre räckte till för att undervisa det allt mer komplicerade innehållet. ${ }^{36}$

34. CJ.,"Dövskolan demonstrerade för mera kontakt i samhället", Borgåbladet 27/9 I980.

35. Salmi, "Kielelliset käänteet kuurojen opetuksessa", s. 30-31.

36. Brita Edlund, "Vilket ljud har ljuset?", Karin Hoyer, Monica Londen \& Jan-Ola Östman (red.), Teckenspråk: Sociala och historiska perspektiv, Nordica Helsingiensia 6, Helsingfors: Nordica 2006, s. I6; Intervju med Birgitta Wallvik 2I/5 2019. Intervjuinspelning i författarens ägo. 
I flera finländska dövskolor uppstod konflikter mellan lärarkåren och eleverna samt deras föräldrar vid denna tid angående teckenspråkets ställning i undervisningen, så även i Borgå. ${ }^{37}$ År 1983 hade Ralf Mattsson tillträtt som ny föreståndare för skolan, men han saknade kunskap i teckenspråket och tidigare erfarenhet av dövundervisning, vilket skolans t.f. föreståndare Ella Björkman såg som bekymmersamt. Björkman hade nämligen själv erfarenhet av att komma in i dövskolan utan att kunna teckenspråk och vittnade om de svårigheter som då uppstod i arbetet. ${ }^{38}$ Några år senare blossade en offentlig debatt mellan Mattsson och Brita Edlund upp i dagspressen, som ett resultat av ett betänkande som en arbetsgrupp vid Undervisningsministeriet givit angående dövundervisningen i samband med grundskolereformen. Enligt betänkandet skulle döva elever ha samma status som samiska elever, eftersom teckenspråket var dövas modersmål och därför borde undervisningen ske på teckenspråk. ${ }^{39}$ Mattsson opponerade sig mot rapporten och menade att teckenspråket inte kunde få den ställning det hade uppnått i Sverige, där språket sedan 198I var erkänt som modersmål, och där undervisningen utgick från principen om tvåspråkighet. Enligt Mattsson satte det här det svenska språket på undantag, vilket gick emot dövundervisningens princip att lära det döva barnet att kommunicera med samhället runtomkring och inte endast med den egna gruppen. ${ }^{40}$

Edlund svarade med att understryka teckenspråkets grundläggande betydelse för döva barn, och likt medlemmarna i Undervisningsministeriets arbetsgrupp betonade Edlund minoritetsperspektivet:

- Döva är en språklig minoritet, förklarar Edlund. Deras modersmål är inte svenska eller finska. Det är teckenspråket. Enligt det betänkande som undervisningsministeriets arbetsgrupp just har gett är också

37. Om problem i andra dövskolor se t.ex. "Eduskuntakysely Mikkelin kuurojen epäkohdista", Tidskrift för Döva I982:II-I2, s. 7-Io. Problemen gällde inte endast undervisningen utan även förhållandena på elevhemmen.

38. Carola Stark, "'Det är som att skiljas från sina egna barn”, Borgåbladet 30/7 I982.

39. "Teckenspråk som modersmål i undervisningen", Hufvudstadsbladet 6/7 I985.

40. Johnny Holmberg, "Modersmålet viktigt", Borgåbladet 3/7 1985. Debatten återpublicerades i Tidskrift for Döva I985:13 och Nappi 1985:4. 
teckenspråket dövas första språk. Den logiska slutsatsen av detta måste vara att dövskolornas undervisningsspråk bör vara teckenspråket. ${ }^{41}$

Vidare menade Edlund att utan kunskaper i det egna modersmålet saknades grunden för all annan inlärning. Edlund lyfte även fram problemet med dövlärarnas bristfälliga kunskaper i teckenspråk och att samma lärare undervisade i både de lägre och de högre klasserna. ${ }^{42}$

Konflikten fortsatte i slutet av i980-talet och i början av i990-talet. År 1988 gjorde Borgåbladet ett stort uppslaget reportage om vad man kallade för krisen vid skolan, där man intervjuade både elever, föräldrar, lärare, föreståndaren och ordföranden för skoldirektionen. Föräldraföreningen hade skickat en skrivelse till skolstyrelsen där man yrkade på förbättringar i skolans ledning. Enligt skrivelsen kände sig eleverna otrygga i skolan på grund av personalens bristande teckenspråkskunskaper och att personalen ofta byttes på elevhemmet. Gustaf Öller, ordförande för DHBS, var i artikeln noggrann med att påpeka att det inte var kollegiet som kritiserades utan ledningen. Dessutom fanns det strukturella och sociala problem som gick ut över själva undervisningen. I skrivelsen talade man också för att de äldre eleverna behövde miljöombyte och mera fritidsaktiviteter. Även aktualitetsprogrammet OBS! uppmärksammade konflikten. ${ }^{43}$

En fråga som togs upp av både vuxna döva och lärarkåren vid dövskolan var behovet av döva förebilder och att vuxna döva borde få ett starkare inflytande över dövundervisningen. I processen att övergå från oralism till teckenspråkig undervisning var ett av målen bland döva att de själva skulle få påverka hur de undervisades. Även gällande den finlandssvenska dövundervisningen framfördes dessa krav, då medlemmarna i den svenska arbetsgruppen vid Dövas Förbund diskuterade frågan. ${ }^{44}$ Kravet uppmärksammades även i samband med Borgåbladets reportage om krisen vid dövskolan. Borgånejdens dövförening skrev efter reportaget en insändare där föreningens re-

4I. Micke Godtfredsen, ”Teckenspråk dövas modersmål”, Borgåbladet 4/7 I985.

42. Ibid.

43. Micke Godtfredsen, "Känslorna kring dövskolan svallar", Borgåbladet 5/3 I988.

44. Arbetsgruppen för kulturcentrumet vid Dövskolan i Borgå, protokoll I4/I I984, Finlandssvenska teckenspråkiga r.f., Helsingfors. 
presentanter storligen förundrade sig över hur skolan beskrevs, och speciellt över att ungdomarna vid skolan skulle vara oroliga. Enligt insändarskribenterna fanns det inga problem vid föreningens träffar där även eleverna deltog och problemen måste vara ett resultat av bristande kommunikationsmöjligheter mellan elever och personal, som saknade kunskap i teckenspråk och dövmedvetenhet. Eftersom eleverna bodde på skolan största delen av tiden, hade skolan en viktig uppfostrande uppgift, och om det fanns brister i hur denna uppgift sköttes kunde det leda till allvarliga problem för eleverna senare i livet. Insändarskribenterna krävde flera döva bland personalen som skulle kunna fungera som förebilder. ${ }^{45}$ Också skolans ledning och lärarkår var inne på samma linje och ansåg att det behövdes döva lärare, eftersom endast de till fullo kunde förstå det döva barnet. ${ }^{46}$

I vilken mån var de problem som uppstod vid dövskolan i Borgå och de diskussioner som fördes kring dövundervisningens ställning mellan skolans ledning och eleverna samt deras föräldrar specifika för det finlandssvenska dövsamfundet? Som jag nämnde tidigare uppstod konflikter i flera skolor, men enligt Salmi och Laakso stack situationen vid Borgåskolan ut som särskilt problematisk, men de ger ingen förklaring till att konflikterna drabbade speciellt den svenska skolan hårt. ${ }^{47}$ Minoritetsförhållandet bör lyftas fram för att man ska förstå situationen. Det finlandssvenska dövsamfundet arbetade inte endast för ett språk, teckenspråket, utan även för svenskan, och den enda institution som kunde förmedla undervisning på de båda språken var Borgå dövskola. Det teckenspråk som användes bland finlandssvenska döva ansågs inte på 1980-talet vara ett eget språk, utan närmast en variant av det finska teckenspråket. En del tecken, så kallade Borgåtecken, och framför allt artikulationen var annorlunda, vilket markerade språklig skillnad. ${ }^{48}$ De svenska döva hade dessutom svenska som

45. Boris Kankkonen m.fl.,"Teckenspråkig miljö i Dövskolans elevhem”, Borgåbladet 29/3 I988.

46. Leif Wikström, ”Döva personer borde utbildas till lärare!”, Borgåbladet 26/9 I986.

47. Salmi \& Laakso, Maahan lämpimään, s. 357-358.

48. Karin Hoyer, "De kallade dem Borgåtecken'. Det finlandssvenska teckenspråket i går och i dag”, Jan-Ola Östman (red.), Nordica Helsingiensia 4, Helsingfors: Nordica 2005, s. 2I-80. Karin Hoyer, "Vähemmistö vähemmistössä: suomenruotsalaiset kuurot ja heidän viittomakielensä", Anja Malm (toim.), Viittomakieliset Suomessa, Helsinki: Finn Lectura 2000, s. 205-215. 
läs- och skriftspråk, vilket innebar att en övergång till en finskspråkig skola för de flesta inte var ett alternativ.

Inom dövundervisningen har resurserna i praktiken alltid först täckt de finska dövas behov för att sedan, om möjligt, förse de svenska döva med liknande möjligheter; därför saknade också de svenska eleverna både tillräckligt skolmaterial och fortsatt utbildning efter avslutad grundskola. För finlandssvenska döva fanns det alltså ingen yrkes- eller gymnasieutbildning i Finland, vilket var en fråga som hade diskuterats allt sedan dövas yrkesutbildning stipulerades i lag 1944. I takt med att utbildningsnivån höjdes under andra hälften av I900-talet, blev det allt vanligare att de finlandssvenska ungdomarna reste till Sverige för att få yrkesutbildning; först hade det varit fråga om enstaka personer som sedan flyttade tillbaka till Finland, men på 1980-talet var flytten till Sverige efter avslutad skolgång i Borgå redan satt i system och för allt fler blev den permanent. Trots att man i Sverige använde sig av ett annat teckenspråk var språken nära besläktade och skriftspråket naturligtvis detsamma, vilket underlättade integrationen i det nya landet. Möjligheterna att på olika sätt stävja den här utvecklingen och förse de finlandssvenska döva ungdomarna med yrkesutbildning i hemlandet, till exempel genom att erbjuda tolkning i yrkesskola för hörande, var en fråga som DHBS arbetade för i början av I980-talet. ${ }^{49}$

Minoritetsställningen innebar alltså en ökad utsatthet, och dubbelminoritetspositionen förstärkte detta ytterligare, vilket den fortsatta utvecklingen med all tydlighet visar. Mot slutet av I980-talet valde nämligen allt flera att avbryta sin skolgång i Borgå och i stället avsluta grundskolan antingen i Sverige eller i en skola för hörande. Det var framför allt österbottniska elever som valde ett annat skolalternativ, men också familjer bosatta i Borgå med flera döva barn valde att flytta till Sverige. Som grund för beslutet låg missnöje med undervisningen och bemötandet av eleverna. ${ }^{50}$ Elevantalet dalade och en arbetsgrupp behandlade mellan 1992 och 1993 frågan hur man skulle kunna hålla skolan vid liv trots sviktande elevunderlag. Staten valde dock att stänga

49. Intervju med Brita Edlund 23/5 2019; intervju med Håkan Westerholm 30/9 2019. 50. Intervju med Brita Edlund 23/5 20I9; intervju med Janne Kankkonen 3/10 2019. Intervjuinspelning i författarens ägo. 
skolan I993, och de finlandssvenska eleverna var förvisade till antingen skola för hörande, finsk dövskola eller dövskola i Sverige. Rätt till utbildning på svenska betydde inte rätt till egen skola, utan kunde $\mathrm{i}$ stället innefatta att staten och kommunerna betalade för skolgången i Sverige eller lönen för en tolk. Även om man under hela I990-talet diskuterade olika alternativ för hur dövundervisningen på svenska skulle återupptas blev det inte något av planerna. Utvecklingen hade nämligen gått i en annan riktning. För det första hade en stor del av det finlandssvenska dövsamfundet flyttat till Sverige, och där övergått till det svenska teckenspråket samt integrerats i det svenska dövsamfundet och hade inga planer på återflyttning till Finland. För det andra började man ge döva barn cochlea-implantat från och med mitten av I990-talet, med vars hjälp barnet uppfattade en del ljud och kunde gå i skola för hörande.

\section{RÄTT TILL INFORMATION PÅ SVENSKA}

Dövas rättigheter handlade dock inte uteslutande om teckenspråkig undervisning. Slutet av 1970-talet och början av i980-talet var en viktig period inte endast beträffande hur dövundervisningen utvecklades, utan för dövsamfunden i stort. Som jag nämnde ovan innebär de finlandssvenska dövas dubbla minoritetsställning att de arbetade för rättigheter på olika fronter, både för teckenspråket och för det svenska språket. Trots att den finlandssvenska minoriteten som helhet har varit tvungen att bevaka och kräva rätten till svenskan, drivs frågan till sin spets då det handlar om en minoritet inom minoriteten såsom finlandssvenska döva.

I frågan om undervisning och övriga frågor som berör döva barn, såsom habilitering, talterapi och hemvägledning var den finlandssvenska tidningspressen aktiv och framför allt Borgåbladet engagerade sig ofta i dövskolans angelägenheter. Dagstidningarna tystnar dock då det handlar om vuxna dövas behov och rättigheter. I den finlandssvenska pressen intervjuades ibland Dövas Förbunds mångåriga ordförande Runo Savisaari, men vuxna finlandssvenska döva blir av intresse för allmänheten först i mitten av i980-talet. Även om tidningspressen inte är en direkt spegel av samhället, ger den en god bild av samhällsengagemanget. 
Även gällande vuxna dövas behov och rättigheter kan man peka ut centrala personer och händelser inom det finlandssvenska dövsamfundet. I slutet av r970-talet blev Alf Bjong, som var aktiv i Jakobstads dövförening, ombedd att gå med i Dövas Förbunds styrelse, och $i$ och med det inleddes ett mångårigt arbete för att uppmärksamma de finlandssvenska dövas särbehov. Dövas Förbund hade grundats år I905 för att verka för dövas intressen och för informationsspridning till döva. Det svenska inslaget var starkt de första decennierna - bland de grundande medlemmarna fanns bland andra Julius Hirn, redaktör vid Hufvudstadsbladet - men ju längre rgoo-talet framskred desto mindre utrymme fick svenskan i förbundet. Samtidigt var förbundet under stora delar av 1900-talet påfallande litet; personalen bestod fram till 1970-talet av en handfull personer som verkade i små och trånga utrymmen på Elisabetsgatan i Helsingfors. Därför saknades resurser för till exempel omfattande material och program på såväl finska som svenska. ${ }^{51}$

Enligt Bjong blev dock avsaknaden av information på svenska ett konkret problem i hans arbete inom styrelsen. Dokument och information fanns endast tillgängliga på finska, vilket blev ett hinder för att finlandssvenska döva skulle kunna ta aktiv del i förbundets arbete och därigenom bevaka sina rättigheter. Vid slutet av 1970-talet saknades dock organ på finlandssvenskt håll som skulle ha värnat om det svenska språket inom Dövas Förbund, och svenskans ställning var helt beroende av vilka personer som råkade vara aktiva. De lokala dövföreningarna på finlandssvenska orter fungerade främst som sociala mötesplatser, gemensamma för finlandssvenska och finska döva. ${ }^{52}$

För att skapa ett finlandssvenskt rum beslöt Bjong och några andra att arrangera en skolträff sommaren 1980 för alla dåvarande och tidigare elever vid dövskolan i Borgå. Enligt Bjong ville man ha ett sammanhang där man kunde umgås på det egna teckenspråket med människor som hade gemensamma erfarenheter från uppväxttiden. Planerna väckte dock viss skepsis bland dövskolans personal och Greta Wisuri, som verkade som föreståndare fram till I979, var svårövertalad då det gällde att överlåta skolans utrymmen till träffen. Träffen, som ägde rum den I7-I8 maj 1980, blev dock en stor framgång med cirka

5. Wallvik, Du måste vara döv för att förstå, s. I2I.

52. Intervju med Alf och Astrid Bjong 31/5 20I9. Intervjuinspelning i författarens ägo. 
I7o deltagare. Programmet under träffen innefattade bland annat tal, uppträdanden och utflykter samt en gudstjänst i Borgå domkyrka. ${ }^{53}$

Träffens viktigaste syfte var det sociala mötet mellan döva med en gemensam uppväxt, ett gemensamt språk och gemensamma erfarenheter, men på sikt skulle den få politiska implikationer. Eftersom träffen hade varit en stor framgång uppgjordes genast planer på liknande träffar, men även på gemensamt arbete för att bevaka de finlandssvenska dövas rättigheter och intressen. Detta arbete startade först som en studiecirkel, som år I98I ombildades till "Kommittén för kurscentrum vid dövskolan i Borgå”. År 1984 omdöptes kommittén till Finlands Dövas Förbunds svenska arbetsgrupp. Arbetsgruppens uppgift var att ombesörja förbundets svenska verksamhet och därmed även att värna om de svenskspråkiga dövas rättigheter. ${ }^{54}$

På samma sätt som i USA på I970-talet då dövmedvetenhetsrörelsen växte var första steget $\mathrm{i}$ arbetet för de finlandssvenska döva att sprida information och skapa förståelse för dövas liv och rättigheter bland döva själva. Därför handlade verksamheten i början om att ordna kurser som på olika sätt kunde bädda för starkare samhällsengagemang och öka deltagarnas kunskapsnivå, vilket även arbetsgruppens namn vittnade om. ${ }^{55}$ På hösten 1982 ordnades därför de första kurserna på svenska i dövmedvetenhet och föreningsteknik, med Sten Ulfsparre och Liisa Kauppinen som talare, båda ledande gestalter inom dövarbetet i Sverige respektive Finland. ${ }^{56}$ På kursen i dövmedvetenhet talade Sten Ulfsparre om dövas självbestämmanderätt och att det i första hand var döva som skulle styra vilka beslut som fattades om deras liv och villkor. Ulfsparre betonade även den teckenspråkiga miljöns vikt för det döva barnet, och betydelsen av att döva barn umgicks med döva vuxna. Kurserna var välbesökta och följdes upp de kommande åren. ${ }^{57}$

53. Ibid.; Tora Mattheiszen,"Förr fick döva inte använda teckenspråk", Hufvudstadsbla$\operatorname{det}$ 18/5 I980; CS.,"Döva, hörande - umgås mera!", Borgåbladet 20/5 I980; Wallvik, Du måste vara döv för att förstå, s. I2I-I22.

54. CS.,"Döva, hörande - umgås mera!"; intervju med Håkan Westerholm 30/9 2019.

55. Karin Saarikoski, "Ny svensk kommitté för vuxenutbildning”, Tidskrift för Döva I981:I4 s. I9-20.

56. Raija Nieminen,"Dövmedvetenhet - seminariet i Malminharju", Tidskrift för Döva I980:2, s. 2I-25.

57. Karin Saarikoski, "Döva vet bättre om döva", Tidskrift för Döva I982:22, s. I8; Birgitta Wallvik, "Givande kurs i mötesteknik", Tidskrift för Döva I983:20, s. I3-I5. 
På kurserna lyftes frågan om de finlandssvenska dövas specialbehov och huruvida dessa bemöttes i tillräckligt hög grad av förbundet, vilket väckte livlig diskussion. I synnerhet bristen på svenskspråkig personal och kommunikation på svenska väckte känslor, och även genklang $\mathrm{i}$ förbundets ledning. I det första numret av Tidskrift för Döva år I983 skrev ordförande Runo Savisaari en ledare om de finlandssvenska dövas ställning. Savisaari var själv från en trespråkig familj; båda föräldrarna var döva, modern finlandssvensk och fadern finsk. I ledaren konstaterade Savisaari att en minoritet alltid har svårt att hävda sig, och att så inte minst är fallet för en minoritet inom en minoritet. Svenskans ställning hade försvagats under årens lopp och undervisningen för finlandssvenska döva var eftersatt. Inom förbundet var det inte heller alltid som svenskan beaktades i utvecklingsarbetet. Savisaari försvarade dock förbundet genom att påpeka att det alltid har haft svenskspråkig personal och att de finlandssvenska döva har beaktats inom flera verksamhetsfält. Han uppmanade dock de finlandssvenska döva som kände sig missnöjda att skriva in till tidningen och berätta vad de ansåg i frågan samt ge råd om hur verksamheten kunde utvecklas. ${ }^{58}$

Det inflöt inga svar. Kan detta tolkas så att de finlandssvenska döva i huvudsak var nöjda med situationen? Enligt Birgitta Wallvik, som från och med I982 verkade som svensk redaktör för Tidskrift för Döva och från 1984 som svensk sekreterare vid förbundet, ska det snarare tolkas som en ovilja att skylta med missnöjet offentligt. ${ }^{59}$ Även det fortsatta arbetet för finlandssvenska döva tydde på detta.

Vilka konkreta frågor arbetade den svenska arbetsgruppen för? De frågor som framträder är utbildning, tolkning och själavård på svenska. Eftersom jag i föregående avsnitt behandlade utbildningsfrågan, fokuserar jag här på de två andra frågorna. Den främsta sociala frågan för döva under I9oo-talets slut var tillgången till tolktjänster. Fram till r970-talet fanns det ingen organiserad tolkning, utan hörande barn till döva föräldrar agerade i de flesta fall som tolkar och därmed även som mellanhänder mellan den döva och den

58. Runo Savisaari, "De svenskspråkiga dövas ställning", Tidskrift för Döva I983:I, s. 20.

59. Intervju med Birgitta Wallvik 2I/5 2019. 
hörande världen. I mera officiella sammanhang fungerade till exempel dövprästerna eller dövlärarna som tolkar, och även diakonissor samt Frälsningsarméns officerare kunde ibland tolka. Tillgången till tolkning var därmed ytterst sporadisk och fungerade helt på frivillig basis. ${ }^{60}$

Tolkningsfrågan var dock av ytterst stor vikt, eftersom avsaknaden av tolkar äventyrade dövas rättssäkerhet, då de flesta inte kunde kommunicera med myndigheter utan tolkningshjälp. På förbundets agenda låg i mitten av I900-talet att främja både utbildning av tolkar och en lagstadgad rätt till tolkningstjänster, men frågan framskred långsamt. I och med att invalidvårdslagen förnyades år 1979 fick döva rätt till sammanlagt I20 timmar tolkning per år. Fram till ı988 var förmånen dock inkomstbaserad, vilket innebar att en del inte var berättigade till avgiftsfri tolkning. ${ }^{61}$

Lagförändringen betydde dock inte en omedelbar förändring i den verkliga tillgången till tolkning, framför allt inte på finlandssvenskt håll, eftersom det inte hade arrangerats någon utbildning i yrket på svenska. Dessutom var de svenska tolkarnas arbete extra krävande i ett tvåspråkigt land, eftersom tolkarna skulle behärska både svenska, finska och de olika teckenspråkvarieteterna som användes i Finland. ${ }^{62}$ Både den svenska arbetsgruppen och DHBS arbetade för utvidgade tolktjänster och framför allt för tolkning mellan svenska och teckenspråk. Tolkens verksamhetsfält var brett och ett av de primära syftena med att utbilda tolkar på svenska var att de skulle kunna verka som studietolkar i gymnasier och yrkesskolor. Som tidigare nämnts saknades utbildning på andra stadiet för finlandssvenska döva och på I980-talet blev det allt tydligare att de som flyttade till Sverige för att få gymnasie- och yrkesutbildning också stannade i landet efter avslutad utbildning. Avsaknaden av yrkesutbildning diskuterades under hela senare delen av I90o-talet och var även den fråga i anslutning till finlandssvenska döva som engagerade finska döva mest om man utgår

6o. Birgitta Wallvik, "'Nog tar du väl över när jag inte mera finns' sa farmor Julia”, Tidskrift för Döva 1982:21, s. 2I-22.

61. Salmi \& Laakso, Maahan lämpimään, s. 275-28r.

62. Intervju med Brita Edlund 23/5 2019. 
från diskussionen på Tidskrift för Dövas sidor. ${ }^{63}$ Eftersom de med svenska som hemspråk var för få för att bilda en egen skola, ansågs tolkningsalternativet vara det enda gångbara för att hindra utflyttning. Tolkningsutbildning på svenska gavs i tre omgångar, först som en kurs I982, sedan som en ettårig utbildning 1986-I987, och slutligen som en treårig utbildning 1990-1993. ${ }^{64}$

Rätten till själavård på svenska, och en egen dövpräst, skulle dominera mycket av arbetet under I980-talet. Minoritetsrättigheter kan bland annat innefatta rätt till modersmålet i utbildning och kontakt med myndigheter, samt värnandet av minoritetskulturen. ${ }^{65}$ En viktig del av dövas kultur och verksamhet har varit knuten till kyrkligt arbete, och medan skolorna länge hade en repressiv inställning till teckenspråket, fanns det en större acceptans för teckenspråket inom det kyrkliga arbetet. ${ }^{66}$

Arbetet bland de finlandssvenska döva sköttes i början av i980-talet av Eino Savisaari, dövpräst vid Åbo ärkestift och Borgå stift. Savisaaris arbetsinsats för döva och de finlandssvenska döva var mångfasetterad; han verkade som Dövas församlingsblads första chefredaktör och i och med sitt engagemang för teckenspråket var han med som lärare på tolkutbildningarna. Savisaaris arbetsbörda var dock tung och han ansåg själv att de svenska döva borde få en egen präst som enkom kunde sköta deras ärenden. Stiftsrådets planer gick dock i motsatt riktning och till Undervisningsministeriet framfördes år 1982 ett förslag om att det inte skulle finnas en särskild präst för de finlandssvenska döva, utan uppgiften skulle skötas av dövprästerna i de tvåspråkiga stiften. Förslaget upprörde de finlandssvenska döva och i flera repriser under I980-talet och i början av I990-talet besökte delegationer från svenska arbetsgruppen och dövskolan ministeriet för att diskutera frågan, vilken blev akut i och med Savisaaris bortgång år I989. År I990 beviljades medel för att inrätta en tjänst, men dessa täckte endast lön för ett år.

63. Se t.ex. signaturen Plm, "Ruotsinkielisten kuurojen ammattiopetus", Kuurojen Lehti 1949:4, s. 53-54; Raija Nieminen, "Yrkesutbildning för döva", Tidskrift för Döva I98r:4, s. 20.

64. Intervju med Brita Edlund 23/5 2019.

65. Se t.ex. Lars Elenius, Nationalstat och minoritetspolitik. Samer och finskspråkiga minoriteter i ett jämförande perspektiv, Lund: Studentlitteratur 2006, s. 9-Io.

66. Salmi \& Laakso, Maahan lämpimään, s. 222-223. 
Även efter att medel hade säkrats för en fast tjänst, var det svårt att hitta personer som var intresserade och uppfyllde kraven för tjänsten. ${ }^{67}$

På det här sättet sammanfattas problemen i anslutning till finlandssvenska dövas rättigheter och behov: bristen på ekonomiska resurser och kompetent personal. För en minoritet i skärningspunkten mellan funktionsvariation och olika språk har det inte endast handlat om att säkerställa resurser, utan även om att skapa ett engagemang för saken. ${ }^{68}$ För båda dessa syften utvecklade svenska arbetsgruppen ett nära samarbete med ledande SFP-politiker, vilket underlättades både genom personliga kontakter och officiella seminarier och möten. En viktig händelse var till exempel det seminarium som svenska arbetsgruppen ordnade i mars 1985 för representanter från ministerierna och ämbetsverken, där man informerade om finlandssvenska dövas behov och önskemål i frågor som undervisning, tolkning och informationsspridning på svenska. Alf Bjong och Håkan Westerholm som representerade den svenska arbetsgruppen framförde att problemen ofta är de samma för både svenska och finska döva, men de blir mera akuta och har större konsekvenser för de finlandssvenska döva. Seminariet ledde till flera konkreta resultat: dels ändrade Dövas Förbund den svenska sekreterartjänsten från en deltids- till en heltidstjänst, dels intensifierades arbetet mellan svenska arbetsgruppen och svenska riksdagsgruppen. Detta ledde på sikt till att medel ur statsbudgeten reserverades specifikt för den svenska verksamheten. ${ }^{69}$

Var detta ett utslag för ett verkligt engagemang för dövfrågor bland politikerna? Kontakten mellan de finlandssvenska dövrättsaktivisterna och finlandssvenska politiker har varit täta, men i de intervjuer jag har gjort med ledande personer inom arbetet för finlandssvenska döva framkommer dock en ambivalens kring hur man upplevde politikernas intresse. En del såg att dövfrågor låg långt nere i prioritetsordningen,

67. Karl-Oscar Skogster,"Arbetsgrupp föreslår två nya tjänster”, Dövas församlingsblad I982:2, s. 3; Bredlund, "Nästa svenska dövpräst - en kvinna?", Dövas församlingsblad I987:4, s. 3;"Handikappsymposium stödde dövas krav", Dövas församlingsblad 1989:4, s. 4-5; Karl-Oscar Skogster,"Egen dövpräst till Borgå stift?”, Dövas församlingsblad I990:2, s. 3-5; Birgitta Wallvik, "Riksdagen beviljade medel för en svensk dövpräst", Dövas församlingsblad 1990:3-4, s. 9.

68. Intervju med Håkan Westerholm 30/9 2019.

69. Intervju med Birgitta Wallvik 21/5 20I9; Birgitta Wallvik, "Seminarium om de svenska dövas ställning", Tidskrift för Döva 1985:7, s. 24. 
medan andra upplevde en stor förståelse för dövas behov. Detsamma kan sägas om förhållandet till Dövas Förbund, och i vilken mån förbundet uppmärksammat svenskan och de finlandssvenska döva.

\section{RÄTT TILL SPRÅK OCH SAMMANHANG - SLUTSATSER}

Enligt Wheatley och Pabsch rör sig dövas rättigheter i skärningspunkten mellan mänskliga rättigheter, språkliga rättigheter och minoritetsrättigheter samt rättigheter för funktionsvarierade. Dessa överlappar varandra, och har under 200o-talet i de europeiska länderna utkristalliserats till teckenspråksrättigheter eftersom det är de flesta döva personers modersmål, teckenspråket, som alla rättighetsanspråk vilar på.

Då man går längre tillbaka i tiden eller studerar en bestämd grupp av döva rör sig rättighetsanspråken inte i mitten av Wheatleys och Pabschs figur. I den här artikeln har jag genom att studera arbetet för finlandssvenska döva på I98o-talet visat hur rättighetsanspråk går från det allmängiltiga, såsom rätt till teckenspråkig undervisning, till det specifika, såsom kampen för renoveringen av skolbyggnaden och en egen dövpräst. Jag har visat att för en liten minoritet, vars levnadsvillkor är känsliga för ändringar och fluktuationer, har de konkreta problemen i samspel med de ideologiska strömningarna igångsatt arbetet och aktivismen. Med slagordet "minoritet inom en minoritet" arbetade medlemmarna i Dövas Förbunds svenska arbetsgrupp och föräldraföreningen DHBS för finlandssvenska dövas rätt till teckenspråkig utbildning, svensk information, svensk service i form av tolkning samt svensk själavård. De språkliga rättigheterna stiger fram som de absolut viktigaste, och begreppet "minoritet" användes som ett retoriskt argument. Anspelningen på "handikapprättigheter" har dock varit svag, och främst aktualiserats genom tolkningsfrågan, även om den varit av mycket stor vikt. I mitt material har jag inte funnit diskussioner som uttryckligen lyft fram mänskliga rättigheter i anslutning till finlandsvenska dövas problem, utan fokus har varit på det konkreta och påtagliga.

Den mångfasetterade minoritetspositionen som finlandssvenska döva levt med har inneburit både utmaningar och möjligheter. Utmaningarna var uppenbara; i fråga om både informationsspridning på 
svenska samt utbildning på svenska och teckenspråk, drabbade bristande resurser alltid finlandssvenska döva först. Som en minoritet inom den svenska språkgruppen i Finland, hade dock finlandssvenska döva möjlighet att göra rättighetsanspråk och det fanns politiska kontakter och kanaler genom vilka dessa anspråk kunde leda till konkreta resultat.

Det hindrade dock inte att Borgå dövskola, som var navet för det finlandssvenska dövsamfundet, stängdes I993, varefter emigrationen till Sverige ytterligare tilltog. Efter stängningen blev arbetet inom både DHBS och svenska arbetsgruppen mindre intensivt. Då föreningen Finlandssvenska teckenspråkiga grundades år 2002 inleddes en ny fas, där fokus flyttades mot att arbeta för det specifika teckenspråket som användes inom det finlandssvenska dövsamfundet, och att få det erkänt som ett eget språk, ett arbete som fick sitt officiella erkännande i och med teckenspråkslagen 2015 . 